\title{
CHARACTER AND HIGH RISK BEHAVIOUR OF DRUG ADDICTS FOR SPREADING HEPATITIS B AND HIV INFECTION IN A SELECTED AREA OF DHAKA CITY
}

\author{
Hakim $\mathrm{M}^{1}$, Ahmad $\mathrm{M}^{2}$, Naher $\mathrm{S}^{3}$, Ali $\mathrm{M}^{4}$, Ahmed $\mathrm{MU}^{5}$.
}

\begin{abstract}
Introduction: The number of drug abusers is increasing in an alarming state in Bangladesh and they are identified as high risk group for developing Hepatitis B and HIV.
\end{abstract}

Objectives: The aim of this study was to find out various information about drug addicts and their behavioural pattern which can guide the future developmental strategies and planning for reduction of spreading hepatitis B and HIV among the vulnerable population.

Methods: This descriptive type of cross sectional study was performed during July 2006 to June 2007 in three different drug addiction treatment clinic in Uttara, Dhaka on high risk behaviour of drug addicts . A total 194 Drug addicts were interviewed individually by using a structured questionnaire.

The questionnaire was filled up by the author during interview. All the data were checked and edited after collection on the spot. Compilation and subsequent tabulation were done manually. Simple technique of data analysis for percentage, average, standard deviations etc. were done with scientific calculator and using SPSS 11.
Results: Out of 194 cases 180 (92.78\%) were male and 114(58.76\%) were unmarried. Most of them $118(60.82 \%)$ were within the age group of 20 to 29 years. They have an average family income of 12456.39 Taka per month. Most of the addicts $73(37.63 \%)$ were students.

Average family size of drug addicts were 6.73 and majority of them $148(76.29 \%)$ resided with parents. Only 16(8.24\%) drug addicts expressed quarrelsome relationship among their parents and 21(10.83\%) stated a bad relationship with other family members. Of them $86(44.33 \%)$ started to have taking drug at an age range between 20 to 29 years and most of them $156(80.41 \%)$ used poly drug.

Heroin $161(82.99 \%)$ ranked top as abused drug. Most of them 143(73.71\%) were influenced by their friends for initiation of drug addiction. The average daily expense for drug was 191.13 Taka per day and most of them 142(73.19\%) had frequency of drug abuse more than once daily. Only 20(10.31\%) were found as Intravenous Drug Users (IDU); $16(80 \%)$ of the IDUs shared same syringe/needle.

1. Lt Col Maksumul Hakim, MBBS, MPH, MPhil, Assoc Prof, Dept of Community Medicine, AFMC, Dhaka. 2. Lt Col Mushtaq Ahmad, MBBS, DFM, MCPS, Assoc Prof \& Head, Dept of Forensic Medicine \& Toxicology, AFMC, Dhaka. 3. Dr. Salma Naher, MBBS, FCPS, MS (Gynae \& Obs), Junior Consultant, Gynaecology \& Obstetrics, Dhaka Dental College. 4. Brig Gen Mohammad Ali, MBBS, MPH, M.Phil, Prof and Head, Dept of Community Medicine, AFMC, Dhaka. 5. Brig Gen Mohsen Uddin Ahmed, MBBS, MPH, Dy Comdt \& Dir Trg, AFMC, Dhaka. 
Among all the addicts 6(3.09\%) were professional blood donor and among the IDU $4(20 \%)$ were professional blood donors. $139(71.65 \%)$ had history of sex without condom. 82(42.27\%) were unaware about high risk behaviour due to lack of adequate knowledge. $185(95.36 \%)$ used to procure drug from black market. 5(25\%) of IDU and $2(1.15 \%)$ of non IDU were found to be Hepatitis B positive though no HIV positive case was found.

Conclusion: Wide spread motivation of the drug addicts and nationwide publicity regarding the ill effects of their high risk behaviour are needed to combat the spread of Hepatitis B/ HIV.

Key-Words: Drug addicts, Hepatitis B, HIV, High risk behaviour.

\section{Introduction}

Drug addiction once largely a western affiliation, has now emerged as a major socio-medical problem in many South Asian countries including Bangladesh. Since the late 1970s, drug use in Bangladesh has been rising and in late 1980s has become a serious burden to the nation. It has been estimated that there are about 1.2 to 1.5 million drug abusers including alcoholics in Bangladesh. Among them $70-80 \%$ are from young generation ranging from age 18-32 years ${ }^{1}$.

The geographical position of this country has placed it in the international drug trafficking network which brought about an abundance of illicit drugs in the country. For this reason the number of drug abusers are increasing in an alarming rate in Bangladesh ${ }^{2}$. In our country, choice of drugs mainly includes opium, opium derivatives (heroin, morphine, pethidine etc.), barbiturates, alcohol, marijuana etc.
Of course the notorious phenesidyle (codeine phosphate) is also available in Bangladesh. Almost all the aforementioned drugs are available here both legally and illegally. Due to this easy accessibility of a variety of drugs and due to preexisting drug seeking environment e.g.-unemployment, political, unrest, evil company of youths, mental weakness, social negligence, absence of good understanding, frustration, etc. a large number of people are getting addicted every day. The use of illegal drugs and crime go hand in hand, Drug users do anything to obtain drugs to satisfy their habit. Variety of crimes most frequently committed by drug users are pick pocketing, theft, robbery, hijacking, extortion etc. The most devastating problem associated with drug use is the spread of HIV among injecting drug users by needle sharing and non-drug users through un protected sexual contact ${ }^{3}$.

A national NGO in Bangladesh-'Rainbow Nari O Shishu Kallyan Foundation' identified four major causes of spreading out HIV in Bangladesh. These include injection/intravenous drug use (by sharing needle), female sex workers (due to lack of safe sex knowledge), gender discrimination (which indirectly force females for commercial or non-commercial sex), homosexually/Hijra (due to lack of HIV/AIDS information). Poverty and illiteracy fueled in proportionally ${ }^{4}$.

Health officials in Bangladesh fear that poor supervision over blood donations can lead to a big rise in HIV and Hepatitis B. Most of the donated bloods in the country are unscreened and much are donated by a small number of regular donors/IDUs who are known to carry diseases. A survey in one area showed that $29 \%$ of commercial blood donors carried hepatitis B, 3.8\% carried hepatitis $\mathrm{C}$ and many others had syphilis. Only the poor sell their blood and many are drug addicts who need the money to pay for their next fix. Aid workers who hand out clean syringes to drug users to reduce the risk of transmitting infections estimate that one in 
five addicts sell their blood. This is one way to transmit HIV ${ }^{5,6}$.

The need of the hour is to focus on promotion of health of drug addict people by identifying their risky behaviour and thus preventing the worse consequence of it.

\section{Materials and Methods}

This descriptive type of cross sectional study was performed during July 2006 to June 2007 in three different drug addiction treatment clinic in Uttara, Dhaka on high risk behaviour of drug addicts . A total 194 drug addicts were interviewed individually by using a structured questionnaire. All the admitted cases (willing) during study period were included in the study. A brief introduction was given verbally to each respondent at the beginning of the interview to explain the purpose and importance of the study. The questionnaire was filled up by the author during interview. All the data were checked and edited after collection on the spot. Compilation and subsequent tabulation were done manually. Simple technique of data analysis for percentage, average, standard deviations etc. were done with scientific calculator and using SPSS 11.

\section{Results}

This study was conducted in three different drug addiction treatment clinics in Uttara of Dhaka City. One hundred and ninety four drug addicts were included in this study. Out of 194 cases 180 $(92.78 \%)$ were male and $14(7.21 \%)$ were female. Majority of the addicts $114(58.76 \%)$ were unmarried. The age ranges of drug addicts were between 15 years and 43 years. The average age was 25.28 years with standard deviation (S.D.) \pm 6.69 Years. The highest proportion $118(60.82 \%)$ of the drug addicts were in the age group 20-29 years followed by 35 (18.04\%) in the age group 30-39 years (Table-I). Among the drug addicts, about 38 percent had no self-income, about 22 percent had income less than Tk. 3000, 16 percent had Tk. 3000 to 6000 , about 9 percent had Tk. 6001 to
10000 and 14 percent had Tk. more than 10000 per month. The average income was 4596.39 taka per month and standard deviation (S.D.) was \pm 5556.10 taka. As the bulk proportion was income less the SD was too wide (Table-II). The majority $81(41.75 \%)$ of the respondent's monthly income were in the income group of $<10000$ Taka, 72 $(37.11 \%)$ were in the income group of Tk. $10001-20000,41(21.74 \%)$ were in the income group of Tk. 20001 and above. None had less than Tk. 3000 per month.

The average income was 12546.39 taka per month and standard deviation (S.D.) was \pm 6494.35 taka (Table-III). Most of the addicts 73(37.63\%) were students followed by businessman 50 (25.77\%) and unemployed 36(18.56\%) (Table-IV). Average family size of drug addicts were 6.73 and majority of them $148(76.29 \%)$ resided with parents. Only $16(8.24 \%)$ drug addicts expressed quarrelsome relationship among their parents and 21(10.83\%) stated to have a bad relationship with other family members (Table-V). Six (3.09\%) were related with social organization where they had fair relationship with other colleagues. Among the study population, $86(44.33 \%)$ started taking drug at an age range between 20 to 29 years and most of them $156(80.41 \%)$ used poly drug. Respondents were inquired about the type of drug they used for addiction. It was found that more than one drug was abused at a time (Table-VI). Heroin secured top position $161(82.99 \%)$ cases followed by 155 $(80 \%)$ cases of Ganja addiction, 88 (45.36\%) Phensidyl, 71 (36.60\%) Alcohol and 32 caes (16.49\%) of abuse with sedatives. Respondents were asked about the cause of starting the habit first. The majority of the respondents 143 (73.71 \%) started their habit first by the influence of their friends, 19 (9.79\%) out of curiosity, 19 (9.79\% \%) for pleasure and $13(6.71 \%)$ to get relief from mental anxiety. (Table-VII). The average daily expense for drug was 191.13 Taka per day and most of them 142(73.19\%) had frequency of drug abuse more than once daily. $185(95.36 \%)$ used to procure drug from black market. 
$139(71.65 \%)$ had history of sex without condom. $48(60 \%)$ of married men and 91(79.82\%) unmarried men had sex without condom. $89(45.88 \%)$ admitted that they had multiple sex partners. 82(42.27\%) were unaware about high risk behaviour due to lack of adequate knowledge. $156(80.41 \%)$ had faced problem like negligence by family members or friends or family disharmony. $104(53.60 \%)$ expressed their desire to abandon this unhealthy habit. Out of 194 cases 147 agreed to perform tests for Hepatitis B. Among 147 respondents $7(4.76 \%)$ were found to be Hepatitis B positive and rest 140 (95.24\%) were found negative (Table-VIII). All 147 cases that underwent above investigations were found to be HIV negative. Among them 5 out of $20(25 \%)$ IDU's and 2 out of 174 (1.15\%) non IDU's were Hepatitis B positive. Regarding antisocial activities, $128(65.98 \%)$ had no response to the question, 37 (19.07\%) were involved in pick pocketing, followed by public nuisance 17 (8.76\%), drug business 7 (3.61\%), sexual crime 3 $(1.55 \%)$ and robbery $2(1.03 \%)$ (Table-IX). Only $20(10.31 \%)$ were found as Intravenous Drug Users (IDU). 16(80\%) of the IDU's shared same syringe/needle. Among all the addicts 6(3.09\%) and among IDU 4(20\%) were professional blood donor. $5(25 \%)$ of IDU and $2(1.15 \%)$ of non IDU were found to be Hepatitis B positive though no HIV positive cases was found.

Table-I: Distribution of respondents by their age $(\mathrm{n}=194)$

\begin{tabular}{|l|l|l|}
\hline Age in Years & $\begin{array}{l}\text { Number of } \\
\text { drug addicts }\end{array}$ & Percentage \\
\hline Below 20 & 33 & 17.01 \\
\hline $20-29$ & 118 & 60.82 \\
\hline $30-39$ & 35 & 18.04 \\
\hline 40 \& Above & 8 & 4.13 \\
\hline Total & 194 & 100 \\
\hline
\end{tabular}

Table-II: Distribution of respondents by their monthly (self) income. $(\mathrm{n}=194)$

\begin{tabular}{|l|l|l|}
\hline Monthly income & $\begin{array}{l}\text { Number of } \\
\text { respondents }\end{array}$ & Percentage \\
\hline Nil & 74 & 38.14 \\
\hline$<3000$ Taka & 44 & 22.68 \\
\hline 3000-6000 Taka & 31 & 15.98 \\
\hline 6001-10000 Taka & 18 & 9.28 \\
\hline Above 10000 Taka & 27 & 13.92 \\
\hline Total & 194 & 100 \\
\hline
\end{tabular}

Table-III: Distribution of the respondents according to their family income. $(n=194)$

\begin{tabular}{|lcl|}
\hline $\begin{array}{l}\text { Monthly family } \\
\text { income (Taka) }\end{array}$ & $\begin{array}{l}\text { Number of } \\
\text { respondents }\end{array}$ & Percentage \\
\hline$<10000$ & 81 & 41.75 \\
\hline $10001-20000$ & 72 & 37.11 \\
\hline 20001 \& Above & 41 & 21.74 \\
\hline Total & 194 & 100 \\
\hline
\end{tabular}

Table-IV: Distribution of the respondents by their profession. $(\mathrm{n}=194)$

\begin{tabular}{|l|l|l|}
\hline Name of profession & $\begin{array}{l}\text { Number of } \\
\text { respondents }\end{array}$ & Percentage \\
\hline Student & 73 & 37.62 \\
\hline Businessman & 50 & 25.77 \\
\hline Unemployed & 36 & 18.55 \\
\hline Housemaid & 9 & 4.64 \\
\hline Day labour & 6 & 3.09 \\
\hline Rickshaw puller & 5 & 2.58 \\
\hline Others & 15 & 7.73 \\
\hline Total & 194 & 100 \\
\hline
\end{tabular}

Table-V: Distribution of the respondents by conflicts with other family members before drug addiction. $(\mathrm{n}=194)$

\begin{tabular}{|l|l|l|}
\hline Conflicts with other & Number of & Percentage \\
\hline family members & respondents & \\
\hline Yes & 73 & 37.62 \\
\hline No & 50 & 25.77 \\
\hline Total & 36 & 18.55 \\
\hline
\end{tabular}


Table-VI: Distribution of the respondents by the type of drug abuse. $(n=194)$

Same respondents use multiple drugs (poly drugs)

\begin{tabular}{|l|l|l|}
\hline Types of drugs & $\begin{array}{l}\text { Number of } \\
\text { respondents }\end{array}$ & Percentage \\
\hline Heroin & 161 & 82.99 \\
\hline $\begin{array}{l}\text { Marijuana (Ganja or } \\
\text { vang or Ganjaras) }\end{array}$ & 155 & 79.90 \\
\hline Phensidyl & 88 & 45.36 \\
\hline Alcohol & 71 & 36.60 \\
\hline Sedatives & 32 & 16.49 \\
\hline Yaba, viagra, others & 24 & 12.37 \\
\hline Pathedine/Morphine & 9 & 4.64 \\
\hline
\end{tabular}

Table-VII: Distribution of the respondents by cause of addiction $(n=194)$.

\begin{tabular}{|l|l|l|}
\hline Causes of addiction & $\begin{array}{l}\text { Number of } \\
\text { respondents }\end{array}$ & Percentage \\
\hline $\begin{array}{l}\text { Influence by friends } \\
\text { (peer pressure) }\end{array}$ & 143 & 73.71 \\
\hline For pleasure & 19 & 9.79 \\
\hline Out of curiosity & 19 & 9.79 \\
\hline Relief of mental anxiety & 13 & 6.71 \\
\hline Total & 194 & 100 \\
\hline
\end{tabular}

Table-VIII: Distribution of the respondents according to the result of HIV/Hepatitis investigation. ( $\mathrm{N}=194)$.

\begin{tabular}{|l|l|l|}
\hline Result & Number of respe & Percentage \\
\hline Hepatitis B positive & 7 & 4.76 \\
\hline Hepatitis B negative & 140 & 95.24 \\
\hline Total & 147 & 100 \\
\hline
\end{tabular}

Table-IX: Distribution of the respondents according to the antisocial activity performed by them $(n=194)$.

\begin{tabular}{|l|l|l|}
\hline $\begin{array}{l}\text { Type of antisocial } \\
\text { activity }\end{array}$ & $\begin{array}{l}\text { Number of } \\
\text { respondents }\end{array}$ & Percentage \\
\hline Pick pocketing & 37 & 19.07 \\
\hline $\begin{array}{l}\text { Public nuisance, } \\
\text { eve teasing }\end{array}$ & 17 & 8.76 \\
\hline Drug business & 7 & 3.61 \\
\hline Sexual offence & 3 & 1.55 \\
\hline Robbery & 2 & 1.03 \\
\hline No response & 128 & 65.98 \\
\hline Total & 194 & 100 \\
\hline
\end{tabular}

\section{Discussion}

This descriptive type of cross sectional study was conducted on the admitted drug addicts in three drug addiction treatment clinics named Green life, Sheba and light house clinic in Uttara, Dhaka. Since this study was done on a limited number of patient only in above mentioned clinics, the result may not reflect the actual picture of drug addicts throughout Bangladesh. A total of 194 drug addicts were interviewed with a structured questionnaire.

Out of 194 cases $180(92.78 \%)$ were male and 14(7.21\%) were female. Majority of the addicts $114(58.76 \%)$ were unmarried. The study reveals that the occurrence of drug addiction is more common among the younger age group. Most of them $118(60.82 \%)$ were within the age group of 20 to 29 years. The average age of the addicts was 25.28 years. $\mathrm{Kabir}^{7}$ showed that the drug addiction was common at the age group of 20 to 30 years with mean age 25.31 years. Arif ${ }^{1}$ found the age ranging from 18 to 32 years. Hussein ${ }^{8}$ showed age ranging from 21 to 30 years with mean 27.25 years. Haque' showed age ranging from 21 to 29 years with mean age of 26.26 years. In this study it has been found that highest portion of the addicts $73(37.63 \%)$ were students followed by businessman $50 \quad(25.77 \%)$ and unemployed $36(18.56 \%)$.

Most of the students were virtually unemployed and had no income. They procured money from pocket money, loan from friends, stealing from parents or by being engaged in anti social activities. Considering these facts one can assume a connection between drug addiction and antisocial activities like theft, robbery, hijacking, pick pocketing, drug business etc. Regarding guardian's occupation most of them $65(52.03 \%)$ were found to be businessmen. The average family income was found to be 12546.39 taka per month. The majority $81(41.75 \%)$ had less than 10000 taka which resembles with Haque ${ }^{10}$ but not with the study of Haque ${ }^{9}$ where average family income per month was 4627.25 taka which probably is due to the fact that the study was carried out long before.Average family size of drug addicts was 6.73 and majority of them $148(76.29 \%)$ resided with parents. Only 16(8.24\%) drug addicts expressed quarrelsome relationship among their parents and 21(10.83\%) had bad relationship with other family members. These findings are almost similar with the study of Haque ${ }^{9}$ where it was $5.88 \%$. Six $(3.09 \%)$ were related with social organizations where they had fair relationship with other colleagues. Of them $86(44.33 \%)$ started 
taking drug at an age range between 20 to 29 years and most of them $156(80.41 \%)$ used poly drug. This study reveals that Heroin 161(82.99\%) ranked top as abused drug followed by $155(80 \%)$ cases of Ganja addiction, 88 (45.36\%) Phensidyl, 71 (36.60\%) Alcohol and 32 (16.49\%) abused with sedatives. Probably the change of trend is due to low cost and easy availability of drug concerned. It is found that most of the addicts abuse with polydrug. They shift from one drug to another depending on availability. Even some of the addicts tried for cheap Aica glue by sniffing process. Most of them 143(73.71\%) were influenced by their friends for initiation of drug addiction. The average daily expense for drug was 191.13 Taka per day and most of them $142(73.19 \%)$ had frequency of drug abuse more than once daily.

The study reveals that peer pressure was the most important factor for drug abuse initiation. 143 $(73.71 \%)$ respondents were influenced by their friends which was found to be $40 \%, 50 \%, 40 \%$, $4 \%$ and $70.59 \%$ in Kabir's ${ }^{7}$, Haq's ${ }^{10}$, Joseph's ${ }^{11}$, Hussein's ${ }^{8}$ and Haque's study respectively. With the above finding it is quite clear that peer pressure is the most common influencing factor of drug abuse initiation. Other causes of drug addiction include curiosity and excitement through use, despair and frustration among youth, following western culture, poverty, continuous failure in works, easy access to drugs, unemployment problem, estranged in love, mental stress due to family matters etc. $185(95.36 \%)$ used to procure drug from black market. 156(80.41\%) had faced problem like avoidance by family members or friends or family disharmony.

In our study, $139(71.65 \%)$ had history of sex without condom. Among them 48(60\%) are married men and $91(79.82 \%)$ are unmarried. $89(45.88 \%)$ admitted that they had multiple sex partners. 82(42.27\%) were unaware about high risk behaviour due to lack of adequate knowledge. 104(53.60\%) expressed their desire to abandon this unhealthy habit. It has been found that only 20(10.31\%) were Intravenous Drug Users (IDU).
$16(80 \%)$ of the IDU's shared same syringe/needle. Among all the addicts 6(3.09\%) and among IDU $4(20 \%)$ were professional blood donors. In Kabir's ${ }^{9}$ study $9.1 \%$ were found to be IDU's and $67.4 \%$ of them shared needle/ syringe ${ }^{12}$.

In this study no HIV/AIDS cases were found but among 147 respondents $7(4.76 \%)$ were found Hepatitis B positive and rest 140 (95.24\%) were negative. Among IDU's 5(25\%) out of 20 and among non IDUs 2 out of 174 (1.15\%) were Hepatitis B positive. In Tahmina's ${ }^{13}$ study $6.2 \%$ and $4.4 \%$ were Hepatitis B positive among IDU's and non IDU's respectively. $5(25 \%)$ of IDU and $2(1.15 \%)$ of non IDU were found to be Hepatitis B positive though no HIV positive case was found. Drug users, especially those injecting intravenously have an increased risk of infection with hepatitis $B$ virus $(\mathrm{HBV})^{14}$, hepatitis $\mathrm{C}$ virus $(\mathrm{HCV})^{15}$ and human immunodeficiency virus $(\mathrm{HIV})^{16}$.

This transmission occurs primarily through parenteral route by sharing contaminated injection equipment17-19. Studies have shown that the prevalence rates of these blood-borne viral infections are higher among drug addicts ${ }^{20-21}$. Sharing of contaminated injection equipment and abnormal sexual behaviour are common in drug addicted persons, thus facilitating viral transmission by either parenteral or sexual route. Although sexual transmission of HBV has been demonstrated in non-injectable drug users ${ }^{22,23,24,25}$.

The surveillance of the Bangladesh AIDS Prevention and Control Programme (BAPCP) from 1989 to January 1997 revealed only one HIV-positive subject among 2,200 drug users. Till August 2000, the total number of anti-HIV positive cases in Bangladesh has been reported to be 157 and most of them were native wage earners who have returned from abroad. In the present study, anti-HIV antibody was not detected in any patient although in neighbouring Myanmar, the rate of HIV among IDUs is the highest (74\% in Yangon city) in the world ${ }^{26}$. 


\section{Conclusion}

This study has revealed that most of the addicts started taking drug in younger age and addiction very largely happens in urban area. Majority of the addicts started their addiction with ganja and shifted to heroine and continued with it. Risky behaviours for HIV/Hepatitis B like sharing needle/syringe, $\mathrm{s}$ ex without condom, professional blood donation etc. are present among drug addicts which can make disaster by spreading $\mathrm{HIV} / \mathrm{Hepatitis} \mathrm{B} \mathrm{in} \mathrm{the} \mathrm{community.} \mathrm{Peer} \mathrm{pressure,}$ unemployment, lack of knowledge and easy availability of drug work as a catalyst for most of the cases of drug addiction. Most of the drug addicts were involved with antisocial activities to earn easy money to meet the expense for their bad habit. Hence wide spread motivation, proper care and treatment of the drug addicts and nationwide publicity of the ill effects of high risk behaviour for spreading HIV/Hepatitis B are needed to combat this burning problem of our nation.

\section{References}

1. Ariff M. Coordination needed for drug demand reduction; In Touch 1997 May;15:3-7

2. Khondoker S I. Neuropsychiatric assessment among drug abusers attending outpatient department centres in Dhaka city (Thesis). Dhaka: National Institute for Preventive and Social Medicine (NIPSOM); 2000: 2-3.

3. Rahman R. Drug abuse in Bangladesh and prevention; In Touch 1996 July;14:2-6

4. HIV/AIDS and Bangladesh. Available from http://www.typepad.com/t/tracback/7591102

5. Chazan D. Bangladesh faces blood risk.1999 October 25. Available from http://www.bbc.com

6. Who is at risk for HIV Infection and How does HIV Become AIDS? Available from http:// www.drugabuse.gov/ResearchReports /HIV/hiv2.html

7. Kabir S H. A study on the recurrence of drug addiction among the patient treated in the drug addiction treatment hospital, (Thesis). Dhaka:
National Institute for Preventive and Social Medicine (NIPSOM); 1997: 23-37.

8. Hossain J. Possible factor leading to drug addiction as stated by drug addicts attending central drug addiction cure centre, Tejgaon, (Thesis). Dhaka: National Institute for Preventive and Social Medicine ( NIPSOM); 1995: 8-9.

9. Haque R. Drug abuse and factors influencing its initiation. (Thesis). Dhaka: National Institute for Preventive and Social Medicine (NIPSOM); 1992: 7-11.

10. Haq M. E. Drug menace of Bangladesh; In Touch 1995 October;8:4-7

11. Joseph W. Manual of drug abuse. 1st ed. New York: Plenum publishing crop. 1988.p. 8-37

12. Hasan M.Drug addiction in Bangladesh . 31 March 2012 available at www.bdnews24.com

13. Tahmina $\mathrm{S}$, Ahmed $\mathrm{T}$, Iqbal A,Islam $\mathrm{M}$ Prevalence and Risk factors of Hepatitis B, Hepatitis C, Immunodeficiency virus infection among drug addicts in Bangladesh. J Health Popul Nutrition 2000 Dec;18(3):145-50

14. Levine OS, Vlahov D, Nelson KE. Epidemiology of hepatitis B virus infections among injecting drug users: seroprevalence, risk factors and viral infections. Epidemiol Rev 1994;16:418-36.

15. Esteban R. Epidemiology of hepatitis $C$ virus infection. J Hepatol 1993;17(Suppl 3):S 67-71.

16. Des Jarlais DC, Friedman SR, Choopanya K, Vanichseni S, Ward TP. International epidemiology of HIV and AIDS among injecting drug users. AIDS 1992;6:1053-68.

17. Levine OS, Vlahov D, Koehler J, Cohn S, Spronk AM, Nelson KE. Seroepidemiology of hepatitis B virus in a population of injecting drug users: association with drug injection patterns. Am J Epidemiol 1995;142:331-41.

18. Alter MJ. The detection, transmission and outcome of hepatitis $\mathrm{C}$ virus infection. Infect Agents Dis 1993;2:155-66. 
19. Friedman SR, Des Jarlais DC, Neaigus A, Abdul-Quader A, Sotheran JL, Sufian M. AIDS and the new drug injector. Nature 1989;339:333-4.

20. Stark K, Schreier E, Muller R, Wirth D, Driesel G, Beinzle U. Prevalence and determinants of anti-HCV seropositivity and of $\mathrm{HCV}$ genotype among intravenous drug users in Berlin. Scand J Infect Dis 1995;27:331-7.

21. Garfein RS, Vlahov D, Galai N, Doherty MC, Nelson KE. Viral infections in short-term injection drug users: the prevalence of the hepatitis $C$, hepatitis B, human immunodeficiency, and human T-lymphotropic viruses. Am J Public Health 1996;86:655-61.

22. Alter MJ, Ahtone J, Weisfuse I, Starko K, Vacalis TD, Maynard JE. Hepatitis B virus transmission between heterosexuals. JAMA 1986;256:1307-10.
23. Rosenblum L, Darrow W, Witte J, Cohen J, French J, Gill PS et al. Sexual practices in the transmission of hepatitis B virus and prevalence of hepatitis delta infection in female prostitutes in the United States. JAMA 1992;267:2477-81.

24. Kingsley LA, Rinaldo CR, Jr., Lyter DW, Valdiserri RO, Belle SH, Ho M. Sexual transmission efficiency of hepatitis B virus and human immunodeficiency virus among homosexual men. JAMA 1990;264:230-4.

25. Islam MN, Islam KMN, Islam N. Hepatitis-B virus infection in Dhaka, Bangladesh. Bangladesh Med Res Council Bull 1984;10:1-6.

26. Chelala C. Burma: a country's health in crisis. Lancet 1998;352:556. 